\title{
Comparative Research On the Globalization and Localization of International Business
}

\section{SUN BO}

Deputy director, department of research, Guangdong University of Foreign studies, China

YAN XU

Master of International Business, Guangdong University of Foreign studies, China

\begin{abstract}
Globalization is the interdependence of each country in political, economic, trade, culture and other aspects, which brings about the process of international integration. In the process of the further development of worldwide economy uniformity, globalization is a trend. However, even if the power of capital can make most business enterprises strive to get some advantages, but the cultural and political differences make them puzzled and untoward. This paper starts from internationalization, describes the advantages and disadvantages in the development of contemporary economy which globalization brings with representative cases. Then introduce the localization, through the comparative analysis of the two concepts, put forward 'glocalization', in order to emphasize that the effectiveness of transnational enterprise management depends on the balance of globalization and localization.
\end{abstract}

KEYWORD: worldwide economy uniformity, glocalization, globalization, localization, international business

\section{INTRODUCTION OF GLOBALIZATION AND INTERNATIONAL BUSINESS}

\subsection{Definition of Globalization and International Business}

Globalization, which we are contacting in our real life every day, is the process of increased interconnectedness among countries most notably in the areas of economics, politics, and culture. Nowadays, globalization seems to be an important tool for businesses to positioning themselves in global business world.

International Business comprises all commercial transactions that take place between two or more regions, countries and nations beyond their political boundaries, it also contains bank for transaction, logistic for good transportation, insurance and people who specialize in international business. Globalization takes shape of other complement international service business as well.

While, when globalization impacts international business, it usually refers to the shift toward a more integrated and interdependent world economy.

\subsection{Influencing factors of International Business}

\subsubsection{Economy and Politics Factors Influence International Business}

There exists national differences in economy systems. Political systems of a country shape its economic and legal systems. It means the economic activities are affected by the government's policy, the country's political environment, and the relationship among countries. With the background of the globalizing, how the politics influence the international business is that using subsidies, tariffs, trade restraints, administrative policies, and the worldwide organizations. As a global government organization, WTO is the most important organization to the International business, it provide a place to deal with the problems and conflicts among international business activities. There also many similar organizations in the world that served for a group of countries, such as APEC. These political factors are always control the operating of international business in the process of globalization.

\subsubsection{Example of Sany Heavy Industry Due to Political Influence}

The case that U.S. President bans the Sany Heavy Industry group's business activity is a good example to illustrate how the politics affect the International business. The Sany Heavy Industry is a second lager construction machinery manufacturer in China, seventh of the world, and the world's largest concrete machinery manufacturer. In September 28, 2012, President Obama issued executive order. On U.S.A national security grounds to ban the RallS Company which associated to build power plants in the United States, the Sany Heavy Industry group that have 
suffered large losses. Then the Sany Heavy Industry group inspired the Ralls Company to put Obama and CFIUS (USA foreign investment review board) on the court. US Court of Appeals for the Federal Circuit ruled the District of Columbia, judged that US President Barack Obama, without due process of law to prohibit a merger cases, and violated the rights of the Sany Heavy Group's US subsidiary company. It judged that the company is entitled to obtain any non-confidential evidences related to what the Obama administration's decision was based on, and gives it an opportunity to respond.

\subsection{International Business Connects Globalization with Our Life}

Globalization makes this world smaller. Without international business, however, globalization makes no sense in our life. It's exactly commercial activities that bridge the connection between globalization and our real world. Where to drink a cup of Coca-Cola, have a money exchange in the bank, listen to exotic music, make an international phone call, tourist to another country could be traced of globalization. Whatever you accept it or not, we are participating in international business everyday and everywhere.

\subsection{The Necessity of Globalization and International Business}

\subsubsection{Benefits of Ford and Geely Through International Business}

Through the course of globalization, it may accelerate the development of each company and increase benefits from the economical development in each nation. For example, Zhejiang Geely Holding Group signed a deal with US auto giant Ford Motor Co. on Mar 28th, 2010 to acquire Ford Motor's Swedish car unit Volvo Car Corporation for $\$ 1.8$ million. For Geely, Volvo represents an opportunity to improve its technology, then to get the world's leading technologies for a reasonable price. The takeover might help Geely take a step forward in competing with other home grown brands. Geely could also learn Volvo's business system and get in the global game, use this opportunity to promote the name Geely world-wide, and learn essential skills to become a global car company, making an access to the world auto market. Volvo would gain access to the rapidly growing car market in China. This was the opportunity to reverse the situation for Volvo, which had lost so much money under Ford's wings. From this view, the deal benefits each company and each country, and it helped the Chinese carmakers get around some obstacles more quickly.

\subsubsection{Globalization and International Business Bring Economic Growth}

Taking China as example, the improvement of international business brought import and export growth in the past days, it is fast-growing that benefits Chinese development.

Table 1-4 Chinese Import \& Export Growth Monetary Unit: Billion Dollars

\begin{tabular}{|c|c|c|}
\hline \multirow{2}{*}{ Year } & \multicolumn{2}{|c|}{ Import\&Export } \\
\cline { 2 - 3 } & Sum & Growth(\%) \\
\hline 2001 & 5096.5 & 7.5 \\
\hline 2002 & 6207.7 & 21.8 \\
\hline 2003 & 8509.9 & 37.1 \\
\hline 2004 & 11545.5 & 35.7 \\
\hline 2005 & 14221.2 & 23.2 \\
\hline 2006 & 17606.9 & 23.8 \\
\hline 2007 & 21738.3 & 23.5 \\
\hline
\end{tabular}

Data Source: Department of Commerce of the People's Republic of China(2008)

\section{INTRODUCTION OF LOCALIZATION}

\subsection{The Necessity of Localization}

\subsubsection{Cultural Differences in Cross-cultural Conditions}

Differences in culture across and within countries can also affect international business and the world economy. When multinational corporations contact management methods, they will always be faced with the different culture, which is radically with their own culture, as well as the different values, thinking, and many other aspects determined by culture. All these will increase the difficulty of multinational operations, and may even lead to the failure of multinational enterprises.

\subsubsection{Necessary to Adapt to Cultural Differences}

Culture of some countries can be supportive of the capitalist mode of production and lowers the costs of doing business there, it may also help firms based in some countries to achieve a competitive advantage in the world economy. It is necessary to understand how cultural differences across and within nations can affect the way in which business is practiced. Although people from other parts of the world wear the same blue jeans, listen to Western popular music, eat at KFC, and drink Coca-Cola, this just because someone has adopted the symbols of modern consumer society but does not mean they have also adopted Western value systems. Underneath the veneer of modernism, deep cultural differences often remain.

\subsection{Companies Localize Their Business Overseas}

Localization is a kind of strategy which demands the corporation marketing products from the local 
customers' perspective, it is also the process of taking international learning and adapting it for local use, whether in law, culture, or custom.

Nowadays local capital is flowing all around the world more freely, services as well as goods and raw materials are traded with increasing frequency all around the world. We can see a lot of internationalized companies have set up overseas business and sent increasing numbers of employees to other country for business. Such reality has posted an urgent problem to those companies who go global, that is, how to localize their business overseas. Looking back the journey of Disney's launching in Shanghai, at the start many opponents were worried that American cultural and entertainment concepts carried by Disneyland might not be suited to Chinese culture. What Disneyland did was to put some Chinese elements in the park, connecting with the concepts carried by Disneyland. It seems that the American culture and ideology are stepping into the hinterland of the oriental culture gradually. It is an international money-making machine by offering more job opportunities and boosting the economy in Shanghai, and gives Shanghai a new showcase. Both Disneyland and China benefit a lot from it.

\subsection{Wal-mart, A Successful Example of Localization}

As the world's largest retailer, Wal-mart is one of the successful examples of localization in international business. The company generated sales of $\$ 345$ billion in the fiscal year ending January 31, 2007. some \$77billion of these sales were generated in 15 nations outside of the united states. Facing a slowdown in growth in the United States, Wal-mart began its international expansion in the early 1900s when it entered Mexico, teaming up in a joint venture with Cifra, Mexico's largest retailer, to open series of super-centers that sell both groceries and general merchandise. Initially the retailer hit some headwinds in Mexico. It quickly discovered that shopping habits were different.Wal-mart adjusted its strategy to meet the local conditions, hiring local managers who understood Mexican culture, As it built up its distribution systems in Mexico, Wal-mart was able to lower its own costs, which it passed on to Mexico's largest retailer, and the country is widely considered to be the company's most successful foreign venture.

\section{GLOCALIZATION}

\subsection{Introduction of Glocalization}

Having a strong command on the local culture and political economy of the host countries are essential factors in conducting a successful localization of a multinational corporation when doing international businesses.
Glocalization, which is combined by the words globalization and localization, proposed by a Japanese economist in the posted article in Harvard Business Review in the late 1980s.It serves as a means of combining the idea of globalization with that of local considerations. It is to say that, global is local. Glocalization is a new kind of theory and ideological trend under the background of globalization with social and economic development, and it means the adaptation of a product or service specifically to each locality or culture in which it is sold.

\subsection{Think Globally, Act Locally}

Under the backdrop of economic globalization, multinational companies' competitive environment and competitive landscape is under going a significant change. On one hand, because of the internationalization of producing, trading, the trend of market globalization, the improvement of transport and communications facilities, the continuous reduction of trade barriers in the business environment, multinational companies need to continue to operate on the basis of scattered in different geographical operating activities to create and maintain their long--term global competitiveness, and to reduce costs while improving the investment returns. It's a essential part of the global strategy, and is called "think globally, act locally".

\subsection{Global Enterprises Should Act Locally On A Long View}

Multinational enterprises should have long-term goal. Transnational business purely should aim to make profits, there is no doubt about it, but some of them even at the expense of the interests of the host country, obsoleting equipment to foreign countries to extend their service life, transfering high-polluting enterprises to the host country to reduce its pollution, or to evasion tax and transfer pricing to harm the interests of the host country, avoid the host country's laws, even the control of the host country economy. These short-sighted behavior will inevitably affect the image of multinational companies, and is not conducive to their long-term development. Multinational companies should set up the same goal with the host country for cooperation, and from the overall interests, taking the needs of both sides into account in order to achieve "win-win" objective. Localized marketing has already become the global marketing strategy of multinational companies is an important choice on a long view.

\subsection{McDonald's Balance of Globalization and Localization}

McDonald's localization strategy in the background 
of globalization paves a wide and bright path for McDonald's to retain and largen its customers. McDonald's adapts its specific strategies in different countries, because a well received product in one country may be offensive in another one. The pork in hamburgers should be replaced by chicken for example. While spreading its market share in China, McDonald's makes a great effort to be accepted by the Chinese. One strive may be that it adjusts its recipes, containing Chinese featured factors to cater for Chinese customers' taste and to express them. More localized efforts in terms of product innovation and publicity ways also help improve its local recognition degree. McDonald's pays attention not only to global marketing strategy, they also combine globalization and localization effectively.

\section{CONCLUSION}

This paper has made some comparative research on the globalization and localization in the basis of international business, and also highlighted the importance of combining the globalization and localization for better performance in the global market competition. For this topic, foreign scholars have made lots of researches related. With the development of society, how to adapt different factors in different countries in the world is the essential point to operate business in the international or global standings.

In short, in order to gain a competitive advantage, multinational companies need to try their best to adapt to local conditions, transfer of technology and cost savings in the pursuit of profit, allowing enterprises to access global expansion while it benefits.

\section{ACKNOWLEDGEMENTS}

This work was supported in part by a grant from Guangdong province science and technology planning project. (2013B040404009)

\section{REFERENCES}

[1] China becomes Volvo's $3^{\text {rd }}$ largest market. October 23, 2010 [Online] Available at: http://www.chinadaily.com.cn/bizchina/2010/10/23/conten t_11449377.htm[Accessed November 9,2014]

[2] G. Cao, JY. Qian. Five Whimsical Lands in Disney, Nov 6, 2010 [Online] Available at: http://www.news365.com.cn/jij/201011/t20101106_28719 33.htm [Accessed Nov 10, 2014]

[3] Glocalization, from Wikipedia, the free encyclopedia [Online] Available at:http://en.wikipedia.org/wiki/Glocalization [Accessed December 9, 2014]

[4] Charles W.L.Hill International Business (Seventh Edition) April, $2009: 4-76$

[5] Jagdish, B. In Defense of Globalization. New York: Oxford University Press. 2004

[6] Held, D., and McGrew, A. The Global transformations Reader: An Introduction to the Globalization Debate, Blackwell Publishing Ltd. 2003

[7] Michel Laroche, Seong-Yeon Park, Recent advances in globalization, culture and marketing strategy: Introduction to the special issue [J] Journal of Business Research, 2013, 66 (8).955-957.

[8] Bartlett, C. A., \& Ghoshal, S. (1989). Managing across borders: The transnational solution. Boston: Harvard Business School Press.

[9] Wall Street Journal (2006), "Firms in China Think Globally, Hire Locally” Wall Street Journal, Feb 27, p. B1.

[10] Parvez Azim; Samreen Azim. 2012. Impact of Constructive Marketing Strategies on Return (Revenue \& Profitability) : A Case Study of Mcdonald's. Journal of Asian Business Strategy: No.7, 153-169

[11] Malcolm McDonald. (2008). Malcolm McDonald on Marketing Planning: Understanding Marketing Plans and Strategy [ILLUSTRATED]. London: 